\title{
Венецианская якорная стоянка у мыса св. Иоанна в Восточном Крыму (конец XIV - первая половина XV вв.)
}

\begin{abstract}
Аннотачия. В коние XIII - XIV вв. правительство Венецианской республики трижды пыталось организовать торговые фактории на Крымском полуострове. Для этой цели на разных этапах исполъзовалисъ как старые византийские города - например, Сугдея, - так и незаселенные бухты, как Провато. Все эти попытки не увенчались успехом. В конце XIV-XVвв. венечианское присутствие в Крыму ограничивается краткими (от одного до трех дней) стоянками судов линии Таны. Основная цель этого исследования - локализачия навигаиионного пункта, известного по венецианским документам как якорная стоянка у мыса св. Иоанна. Сопоставлены три основные категории источников: писъменные свидетельства, данные картографии, а также археологические материаль, касающиеся якорной стоянки. В Средние века именем св. Иоанна обозначался мыс, современное название которого Киик-Атлама. Сплошньми археологическими разведками на побережъе Восточного Крыма удалось определить место расположения этой якорной стоянки. Руинированные остатки навигачионного пункта находятся в восточной части берега Тихой бухты. В 2000 г. здесъ были проведены археологические раскопки, в результате которых получены материальные свидетельства, позволивиче точно локализовать в этом месте венечианскую якорную стоянку у мыса св. Иоанна.
\end{abstract}

Ключевые слова: Венечианская республика, Генуя, Генуэзская Газария, Восточный Крым, мыс св. Иоанна, Провато, Золотая Орда, картография, археологические исследования, мыс Киик-Атлама.

Abstract. At the end of the 13th - 14th centuries the administration of the Republic of Venice thrice tried to establish trading posts on the Crimean peninsula. For this purpose they used at different stages both old Byzantine towns, such as, for example, Sudak, and unpopulated bays, such as Provato. All these attempts were not met with success. At the end of the 14th-15th centuries the Venetian presence in Crimea was limited to brief (from one day to three) ship moorage on the line to Tana. The main aim of this study is to localise the navigational point known in Venetian documents as the anchorage at the cape of St. John. The author compares three principal source types: written evidence, cartographical data, as well as archaeological material concerning this anchorage. The modern-day cape of Kiyik Atlama was named during the Middle Ages as the cape of St. John. The location of this anchorage has been established through the systematic archaeological investigations on the coast of Eastern Crimea. The ruined remnants of this navigational point were located in the eastern part of the shore of Tikhaya Bay. In 2000 this was the location of extensive archaeological excavations which uncovered material evidence allowing to precisely identify this location with the Venetian anchorage at the cape of St. John.

Key words: Republic of Venice, Genoa, Genoese Gazaria, Eastern Crimea, cape of St. John, Provato, Golden Horde, cartography, archaeological studies, cape of Kiyik Atlama.

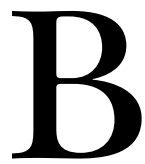
истории итальянских морских республик XIII-XV вв. регион Северного Причерноморья занимает важное место. Позиции Венеции были сильнее в Приазовье, здесь их основным торговым пунктом была Тана - часть золотоордынского города Азака $[1,141 ; 2,1236 ; 3,91-93 ; 4,24 ; 5$,
383-384]. Генуя доминировала на Крымском полуострове, где располагался ее основной форпост - город Каффа. К концу XIV в. Генуэзская республика создаст целую сеть городов, замков, селений в Крыму и Северном Причерноморье, которая в современной литературе получила наименование Генуэзская Газария $[6,12]$, в то

Исследование подготовлено в рамках работы по проекту «Причерноморье и Средиземноморский мир в системе отношений Руси, Востока и Запада в Средние века», поддержанному

Российским научным фондом (соглашение № 14-28-00213 от 15 августа 2014 г. между

Российским научным фондом и МГУ имени М. В. Ломоносова). 
Карта юго-восточной части Крыма. 1 - Каффа (Феодосия); 2 - Солдайя

(Судак); 3 - Солхат

(Старый Крым);

4 - селение Калиера

(Курортное); 5 - селение

Посидима (Коктебель);

6 - якорная стоянка

Провато; 7 - якорная стоянка у мыса св. Иоанна.

(Карта выполнена

Д. И. Неяченко по материалам

С. Г. Бочарова).
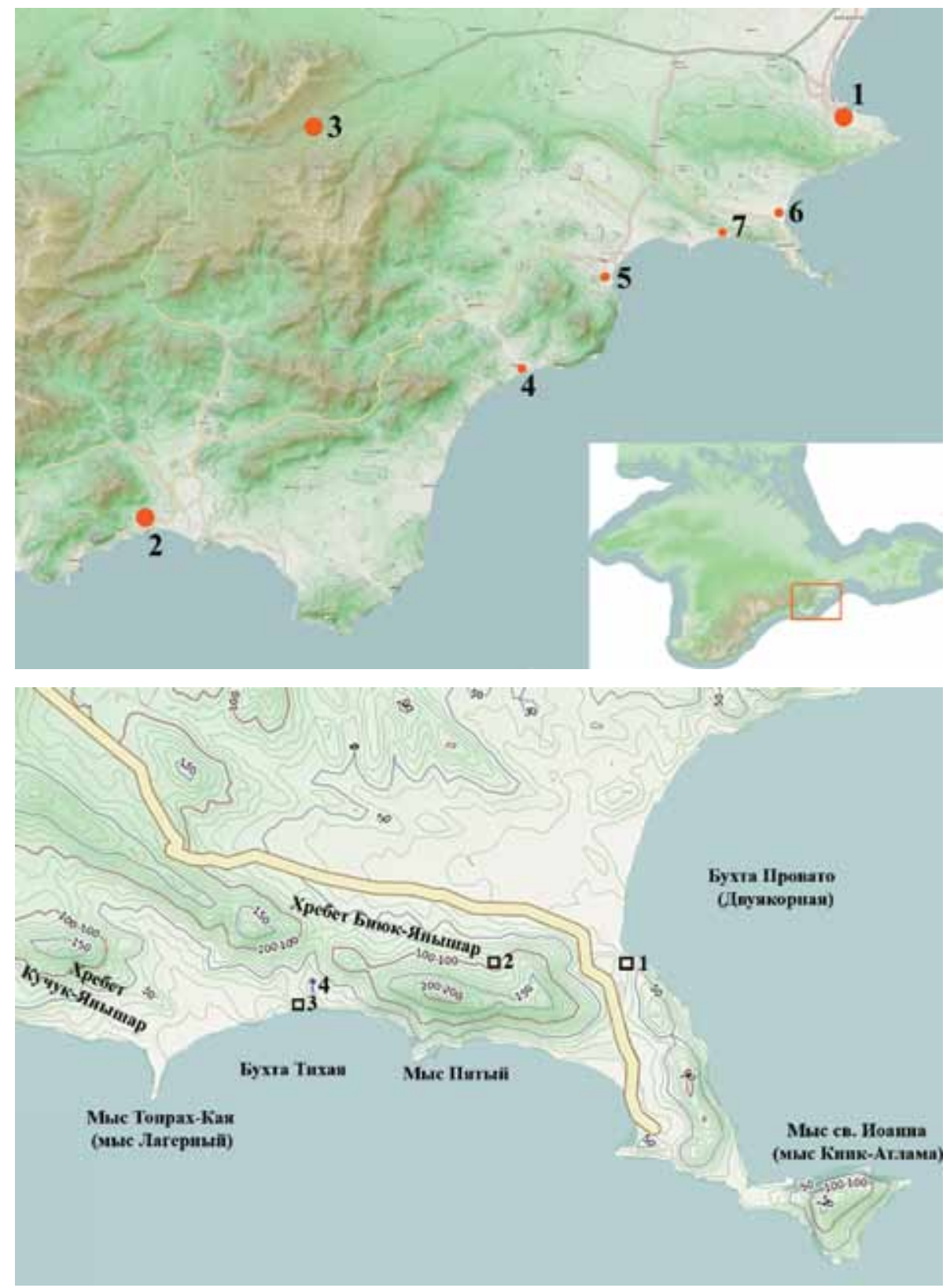

Карта района Тихой бухты. 1 - венецианская якорная стоянка Провато;

2 - армянский монастырь св. Иоанна Предтечи;

3 - якорная стоянка у мыса св. Иоанна (поселение

в Тихой бухте); 4 - родник.

(Карта выполнена

Е. А. Лесной

по материалам

С. Г. Бочарова).

время как венецианское присутствие в регионе так и будет связано с единственным местом - Таной. Но это не значит, что Республика св. Марка не пыталась расширить зону своего влияния в Северном Причерноморье и в дополнение к Тане получить во владение новые пункты на Крымском побережье. Таких попыток было три.

Первая попытка связана со старым византийским центром в Восточном Крыму - городом Сугдея (Солдайя, Судак) - и относится к последней трети XIII в. Венецианцам удалось основать свою первую факторию на Крымском полуострове в этом городе, который находился под властью монгольских ханов [7, 80; 8, 230]. Солдайю пришлось покинуть в первом десятилетии XIV в. во время конфликта с Золотой Ордой $[9,18-20]$.

Вторая попытка приходится на 1347 г. Правительство Венецианской республики обращается к золотоордынскому хану Джанибеку с просьбой предоставить место под устройство торгового поселения в Воспоро (Боспор, Керчь) [10, 336-339]. Судя по отсутствию какихлибо дальнейших свидетельств, Джанибек не 


\section{Исторический журнал: научные исследования № 6 (30) • 2015}

DOI: 10.7256/2222-1972.2015.6.17435
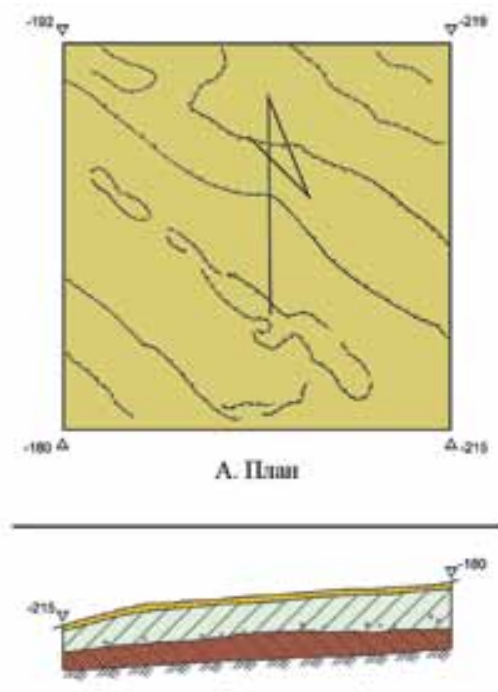

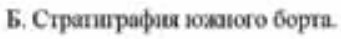

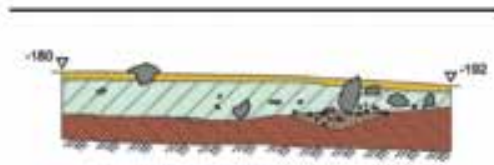

B. Crpanurpaфus samamoro 6opra.

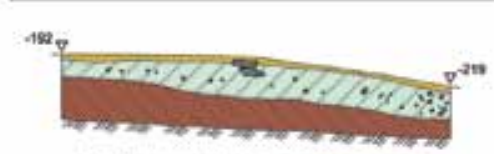

Г. Cтратирафав сепериoro 6 opra.

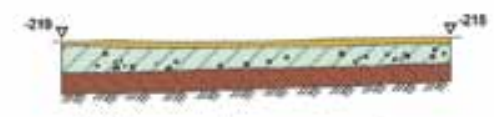

A. Crpanepadus nocrownoro 6opra.
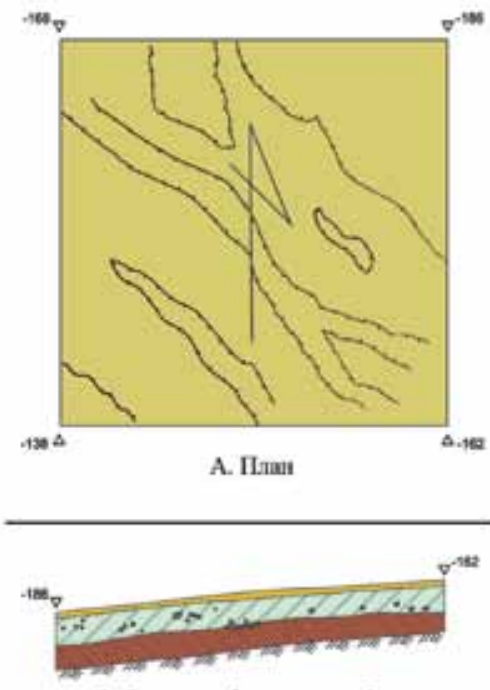

Б. Crратирафия ковного борга.

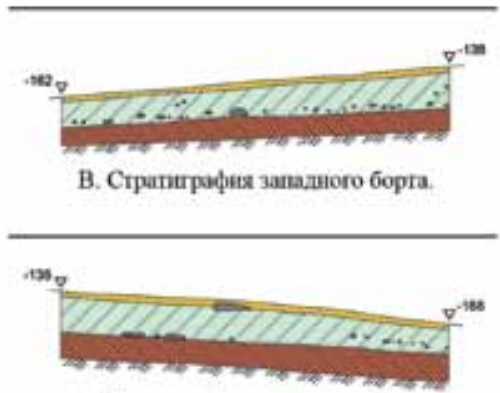

Г. Стратиграфив сенериюго 6орта.

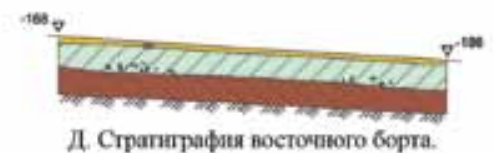

Packoun 5.

Pencons

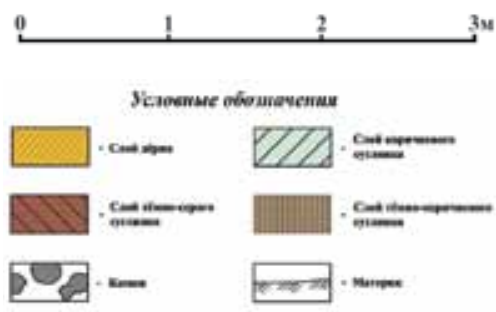

Packon 4.

\author{
Тихая бухта (стоянка \\ у мыса св. Иоанна). \\ Планы и стратиграфии \\ раскопов 4 и 5 . \\ Археологические \\ исследования 2000 г.
}

позволил венецианцам обосноваться на берегу Керченского пролива.

Третья попытка закрепиться на полуострове была предпринята Венецией в середине 50-х начале 80-х гг. XIV в., став самой длительной по времени и значительной по территориальному охвату. Как и во втором случае, она была связана с временной потерей венецианцами Таны. Гражданам Генуи и Венеции запрещалось в течении трех лет посещать этот город - такую норму закрепил подписанный 1 июня 1355 г. Миланский мир, который положил конец венециано-генуэзской войне 1350-1355 гг. [11, 265]. Венецианцы временно теряют свой главный опорный пункт, в то время как генуэзцы сохраняют свой крымский форпост - Каффу. Венецианская республи- ка попыталась перенести центр торговой активности из дельты Дона в Восточный Крым. Первым шагом в этом направлении стало получение от хана Джанибека весной 1356 г. разрешения на устройство торгового поселения у бухты Провато в Восточном Крыму, в 10 км западнее Каффы [12, 25-26; 13, 156; 14, 170-172]. Провато становится конечной точкой венецианской торговой навигации. Именно сюда в 1356 и 1357 гг. заходят галеи линии на значительные сроки - продолжительностью 9-10 дней [15, 55, 64]. Затем в 1358 г. венецианцы еще более расширили свое присутствие в Крыму. Новый хан Бердибек подтвердил их право на владение портом Провато, а также разрешил использовать гавани Солдайи и Калиеры [12, 51-52; 16, 30; 14, 192-193]. 
Тихая бухта (стоянка у мыса св. Иоанна).

Находки из раскопа 4. Археологические исследования 2000 г. Слой коричневого суглинка: 1, 2, 4, 6, 7 фрагменты поливных чаш, мисок и кувшинов (Каффа,

$\mathrm{XV}$ в.); 3, 5 - фрагменты поливных монохромных чаш (Солхат, вторая половина XIV в.).
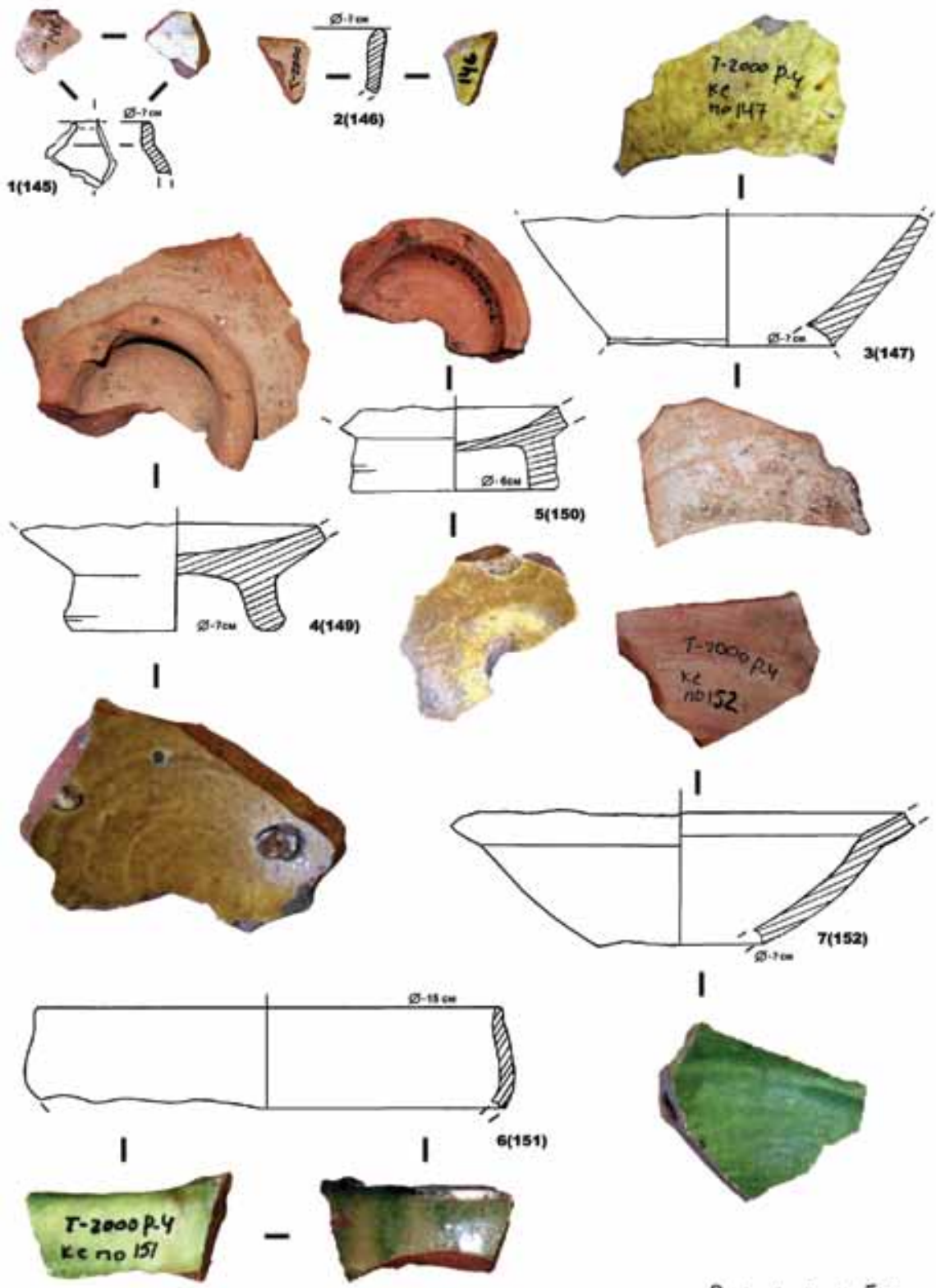

I

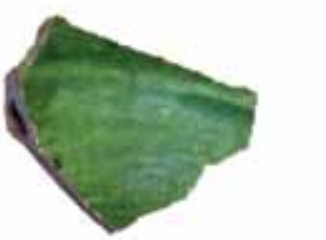

$0+3 \div 5 \mathrm{~cm}$
Длительная гражданская война в Золотой Орде («великая замятня») и захват генуэзцами городов Солдайи, Чембало, Воспоро и их сельских округ $[17,187 ; 18,161 ; 19,15]$ не позволили осуществиться планам Республики св. Марка по закреплению на Крымском побережье. В дальнейшем венецианцы попыток возобновить свои стационарные торговые станции на полуострове не предпринимали, но галеи линии Таны продолжали совершать краткие (от одного до трех дней) остановки с целью пополнения запасов воды и провизии в Каффе, Херсоне (Херсонесе) и в пункте, именуемом мысом св. Иоанна [15, $55,72]$. И если нахождение Каффы в Восточном Крыму и Херсона в Юго-Западном Крыму понятно, то место расположения стоянки у мыса св. Иоанна неизвестно.

Темой нашей статьи мы выбрали именно якорную стоянку у мыса св. Иоанна. В настоящем исследовании необходимо ответить на три основных вопроса: какой мыс в Средние века носил имя св. Иоанна, где относительно мыса находилась якорная стоянка и какие остались материальные следы этого навигационного пункта. 


\section{Исторический журнал: научные исследования № 6 (30) • 2015}

DOI: $10.7256 / 2222-1972.2015 .6 .17435$

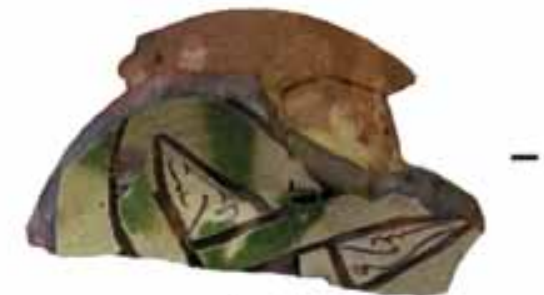

I

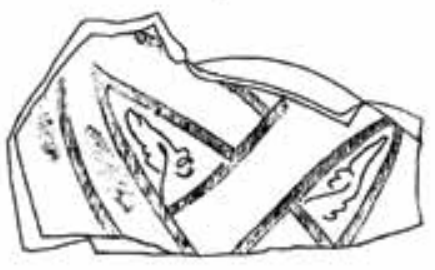

.

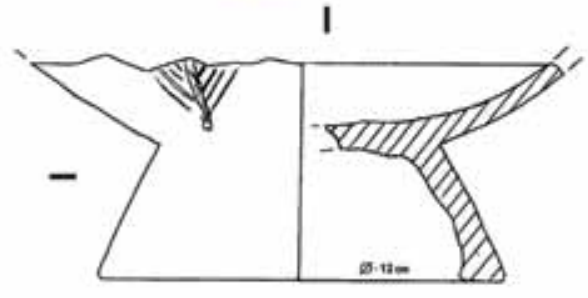

1(174)
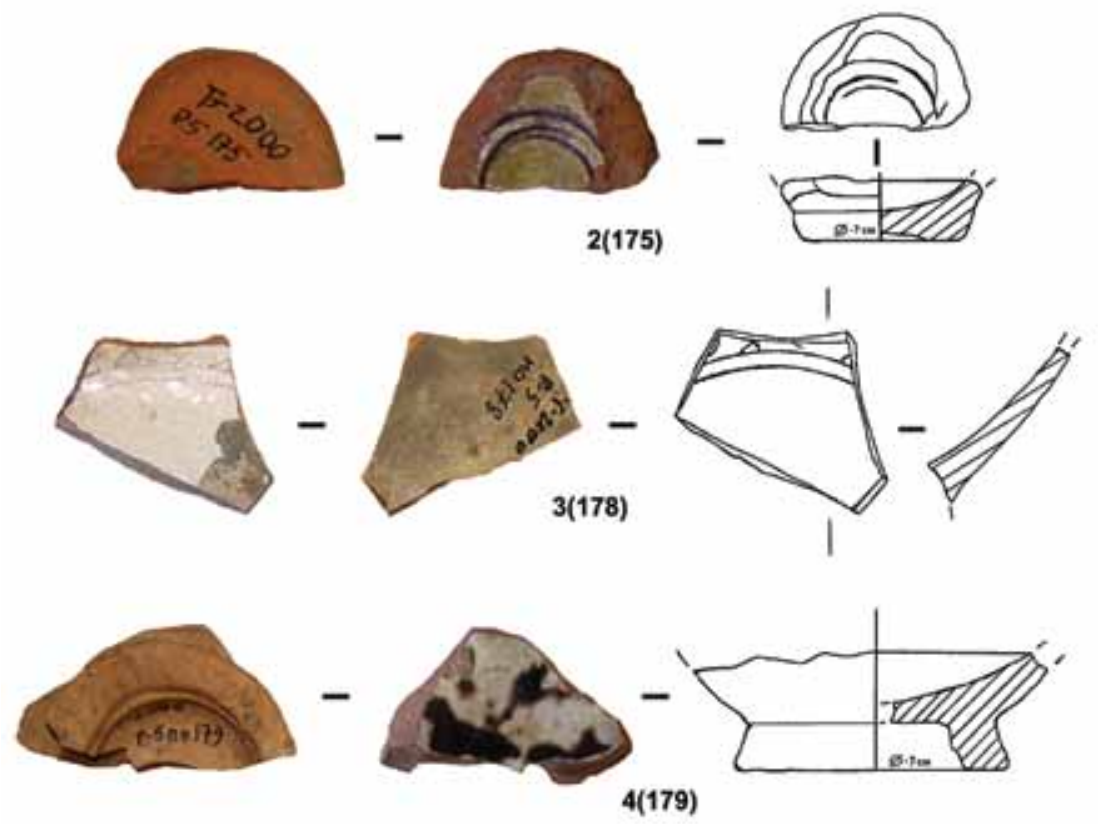

$0+2,5 \mathrm{em}$
Тихая бухта (стоянка у мыса св. Иоанна).

Находки из раскопа 4. Археологические исследования 2000 г. Слой коричневого суглинка: 1, 3 - фрагменты поливных монохромных чаш (Солхат, вторая половина XIV в.);

2 - фрагмент поливного кубка византийского производства (Константинополь, вторая половина XIV в.);

4 - фрагмент поливной чаши с росписью марганцем (Солхат, 1330-1340 гг.).
Венецианские суда делали остановки у мыса св. Иоанна в 1396 г. на три дня, в 1397 г. на два дня, в 1399 г. на два дня и в 1433 г. на один день [15, 65]. На средневековых компасных картах интересующий нас мыс не обозначен $[20,273]$. На портоланах между Каффой и Солдаей отмечены три пункта в направлении с востока на запад - Провато (Provato), Посидима (Possidima), Калиера (Caliera) - и один мыс Меганом (Meganomo) [21, 89; 22, 61; 20, 273, 321]. На основании изучения венецианских документов С. П. Карпов отмечает, что мыс св. Иоанна расположен недалеко от Каффы и кратковременные стоянки в этом пункте для пополнения запасов продовольствия и товаров делались, чтобы корабли не заходили в генуэзскую Каффу, где налоги, взымаемые с иностранных судов, были очень высокими [15, 57].

Локализовать мыс св. Иоанна могут помочь данные топонимики. С юго-запада каффийскую бухту завершал мыс св. Ильи. Далее - в западном направлении - следовали мыс и горный хребет, современное название которого Киик-Атлама, что в переводе с тюркского - прыжок лани [23, 36]. Заканчивается этот мыс небольшим островком, носящим название Иван-баба (в переводе с тюркского - отец Иоанн или священник Иоанн). То есть в данном случае мы имеем точный 
перевод на тюркский более ранних латинских и греческих названий. Средневековое греческое название выдающегося в море хребта -

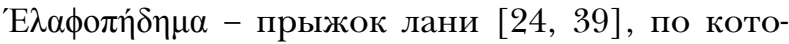
рому получило название и селение на месте современного Коктебеля - Посидима [25, 12; 26], следовательно, средневековое название оконечности этого хребта, используемое латинянами, мыс св. Иоанна. В пользу подобной локализации топонима, по нашему мнению, свидетельствует и название армянского монастыря в честь Иоанна Предтечи, который расположен в 1,5 км северо-восточнее этого мыса $[27,140]$ (рис. 1).

Если предложенная нами локализация мыса св. Иоанна верна, то севернее мыса располагалась бухта Провато (современно название Двухъякорная), в которой венецианцы безуспешно пытались обустроить свое торговое поселение [28], и якорную стоянку у мыса св. Иоанна надо искать южнее этого мыса. Единственное место в пространстве от мыса св. Иоанна (современный мыс Киик-Атлама) до входившего в сельскую округу генуэзской Каффы селения Посидима (Коктебель), отвечающее требованиям, необходимым для якорной стоянки, находится в современной Тихой бухте (рис. 2). У этого места удобное географическое расположение: с севера подходы к нему закрывает хребет БиюкЯнышар, а с запада и востока - отдельные возвышенности, также здесь находится единственный на побережье родник с чистой водой. С целью поиска места расположения венецианской якорной стоянки у мыса св. Иоанна Восточно-Крымской (Феодосийской) экспедицией Крымского филиала Института археологии НАНУ была проведена программа натурных археологических исследований и раскопок на территории Тихой бухты, которая была подкреплена архивными изысканиями и выполнялась с перерывами с 1998 по 2001 гг.

В 2000 г. на этой территории были проведены археологические раскопки разведочного характера, которые выявили здесь культурный слой XIV-XV вв. (рис. 1; 2). Поселение площадью примерно 40 на 100 метров располагалось в Кучук-Янышарской долине, вблизи береговой линии Тихой бухты, у северного склона прибрежного безымянного холма с высотной отметкой 19,0 метра. Впервые наличие археологических находок на этом месте было отмечено в дневниковых записях В. И. Веселова в 1957 г. Три четверти площади поселения, на которой выявлен подъемный материал, занято пашней совхоз-завода «Коктебель», в южной части поселения проходит грунтовая дорога из Коктебеля в Тихую бухту. Часть территории памятника у подножия северного склона безымянного холма оказалась непотревоженной. Планировку объекта ни на распаханном участке, ни на затянутом дерном визуально определить не удалось. На поселении были заложены два разведочных раскопа - 4 и 5 (по общей нумерации) - размером 3,00 на 3,00 метра. Глубина культурных напластований - 0,32-0,56 метра, а сами напластования показали одинаковую стратиграфическую ситуацию: слой дерна, слой коричневого суглинка и предматериковый слой темно-зеленой глины (рис. 3). Строительные остатки на вскрытых раскопами участках не зафиксированы [29, л. 50-57].

Находки были сделаны в тонком слое (толщина - 0,18-0,25 метра) коричневого суглинка. Они представлены фрагментами: амфор группы «Трапезунд» (XIII-XIV вв.) [30, 87-96; 31, 381-383], поливной чаши с росписью марганцем (Солхат, 1330-1340 гг.) [32, 99] (рис. 5, 4), поливного кубка византийского производства (Константинополь, вторая половина XIVв.) [33, 33] (рис. 5, 2), поливных сосудов - монохромных и с орнаментом сграфитто (Солхат, вторая половина XIV в.) [34, 5; 31, 355, 360364] (рис. 4, 3, 5; 5, 1, 3) и поливных чаш, мисок и кувшинов (Каффа, XV в.) [35, 16; 36, 17; $37,27]$ (рис. 4, 1, 2, 4, 6, 7). Полной публикации всех находок керамики из двух раскопов будет посвящена отдельная статья. На основании корреляции артефактов из слоя коричневого суглинка поселение в Тихой бухте можно предварительно датировать XIV-XV вв.

Тонкий и не насыщенный находками культурный слой, маленькая площадь поселения, расположенного в непосредственной близости от единственного в этой части побережья родника, полученная в ходе археологических исследований дата позволяют сделать вывод, что именно это место использовалось венецианцами для кратких стоянок и пополнения запасов провизии и воды и носило название стоянки у мыса св. Иоанна.

В заключение отметим, что в Средние века мысом св. Иоанна назывался мыс, сегодня именуемый Киик-Атлама. Венецианская якорная стоянка у мыса св. Иоанна находилась с юго-западной стороны от этого мыса, на побережье современной Тихой бухты - в непосредственной близости от хорошо известной 


\section{Исторический журнал: научные исследования № 6 (30) • 2015}

\section{DOI: $10.7256 / 2222-1972.2015 .6 .17435$}

венецианским мореплавателям бухты Провато (современное название - Двухъякорная), где в 60-80-х гг. XIV в. Республика св. Марка пыталась основать свой торговый пункт. Место расположения якорной стоянки выгодно отличалось от размещения пункта Провато более значительным удалением на запад от генуэзской Каффы (теперь их разделяли два горных хребта) и относительно трудной доступностью со стороны суши. Материальные следы венецианской якорной стоянки у мыса св. Иоанна нашли отражение в культурном слое небольшого поселения в Тихой бухте, где галеи линии Таны могли пополнять запасы воды и продовольствия, а также делать краткие стоянки в $1396,1397,1399$ и 1433 гг.

Библиография:

1. Волков И. В. Гостевая церковь - мечеть Баязида Вели в Азове // Историко-археологические исследования в г. Азове и на Нижнем Дону в 1989 г. Азов: Издательство Азовского краеведческого музея, 1990. Вып. 9. С. 136-150.

2. Волков И. В. Оборонительные сооружения венецианской Таны (XV в.) // Резюме сообщений XVIII Международного конгресса византинистов. Москва: Предприятие «ПОИНТ», 1991. Ч. ІІ. С. 1236-1237.

3. Волков И. В. Азовская крепость глазами Эвлии Челеби и русских военных топографов XVII-XVIII вв. // Историческая география Дона и Северного Кавказа / Под ред. В. Е. Максименко и В. Н. Королева. Ростов-на-Дону: Издательство Ростовского университета, 1992. С. 83-94.

4. Карпов С. П. Венецианская Тана по актам канцлера Бенедетто Бьянко (1359-1360 гг.) // Причерноморье в Средние века / Под ред. С. П. Карпова. СПб.: Алетейя, 2001. Вып. 5. С. 9-26.

5. Масловский А. Н. Заметки по топографии золотоордынского города Азака // Генуэзская Газария и Золотая Орда / Под ред. С. Г. Бочарова и А. Г. Ситдикова. Казань; Симферополь; Кишинев: Стратум, 2015. С. 383-411.

6. Карпов С. П. Латинская Романия. СПб.: Алетейя, 2000. 253 с.

7. Thiriet F. De l'importance des mers dans le système romaniote de Venise // Byzantino Bulgarica. 1981. Vol. 1. P. 73-86.

8. Martin M. The Venetians in the Black Sea: a general survey // Rivista di Bizantinistica. 1993. T. 2. P. 227-248.

9. Nystazopoulou-Pélékidis M. Venise et la mer Noir du XIe au XVe siècle // Thesaurismata. 1970. Vol. 7. P. 15-51.

10. Diplomatarium Veneto-Levantinum, sive Acta et Diplomata res Venetas, Graecas atque Levantis illustrantia. 1880. A. 1300-1350 / Ed. by G. M. Thomas. P. 1. Venetiis: Sumptibus Societatis, 1880.396 p.

11. Скржинская Е. Ч. Петрарка о генуэзцах на Леванте // Византийский временник. 1949. Вып. 2 (27). С. 245-266.

12. Diplomatarium Veneto-Levantinum, sive Acta et Diplomata res Venetas, Graecas atque Levantis illustrantia. 1899. A. 1351-1454 / Ed. by R. Predelli. P. 2. Venetiis: Sumptibus Societatis, 1899. 278 p.

13. Григорьев А. П., Григорьев В. П. Уведомление правителя Крыма Рамадана венецианским купцам в Янгишехре (1356 г.) // Востоковедение. 1997. Вып. 36. С. 155-159.

14. Григорьев А. П., Григорьев В. П. Коллекция золотоордынских документов из Венеции. СПб.: Издательство СанктПетербургского университета, 2002. 274 с.

15. Карпов С. П. Путями средневековых мореходов. Черноморская навигация Венецианской республики в XIII-XV вв. M.: Восточная литература, 1994. 158 с.

16. Григорьев А. П. Золотоордынский город Ягнишехр // Вестник Ленинградского государственного университета. Сер. 2. 1994. Вып. 2. С. 28-38.

17. Vasiliev A. A. The goths in the Crimea. Cambridge, Massachusetts: The Medieval Academy of America, 1936. 293 p.

18. Balard M. La Romanie Génoise (XIII-e - début du XV-e siécle). Roma; Genova: Boccard, 1978. T. 1. 494 p.

19. Basso E. Il "bellum de Sorchati” ed i trattati del 1380-1387 tra Genova e l'Ordo d'Oro // Studi genuensi. 1991. Vol. VIII. P. 11-26.

20. Фоменко И. К. Образ мира на старинных портоланах. Причерноморье. Конец XIII - XVII в. М.: Индрик, 2007. 396 C.

21. Бочаров С. Г. Заметки по исторической географии генуэзской Газарии XIV-XV веков // Проблемы истории и археологии Украины. Материалы международной научной конференции. Харьков: Издательство Харьковского национального университета, 2001. С. 89-90.

22. Фоменко И. К. Номенклатура географических названий Причерноморья по морским картам конца XIII - XVII вв. // Причерноморье в средние века / Под ред. С. П. Карпова. СПб.: Алетейя, 2003. Вып. 3. С. 40-108.

23. Белянский И. Л., Лезина И. Н., Суперанская А. В. Крым. Географические названия. Симферополь: Таврия Плюс, 1998.160 с.

24. Delatte A. Les portulans grecs. Liège: Université de Liège, 1947. 399 p.

25. Бочаров С. Г. Рубеж XIII-XIV вв. по материалам керамического комплекса поселения Посидима (Коктебель) // Тезисы II Международной научной конференции «Поливная керамика Восточной Европы, Причерноморья и Средиземноморья в X-XVIII вв.» / Под ред. С. Г. Бочарова. Ялта: Издательство Вендеревских, 2007. С. 12-18.

26. Бочаров С. Г. Средневековое селение Посидима (Коктебель, Крым) // Вестник Казанского государственного университета культуры и искусств. 2015. Вып. 3. С. 123-127.

27. Бочаров С. Г. Заметки по исторической географии Генуэзской Газарии XIV-XV веков (Кампанья Каффы) // Диалог городской и степной культур на евразийском пространстве. Материалы Международной научной конференции, посвященной 80-летию со дня рождения Г. А. Федорова-Давыдова / Под ред. Д. В. Васильева, Ю. А. Зеленеева и А. Г. Ситдикова. Казань: Издательство Института истории Академии наук Республики Татарстан, 2011. 137-145.

28. Бочаров С. Г. Венецианское присутствие в Крыму и якорная стоянка Провато в 1356-1382 гг. // Стратум Плюс. 2015. Вып. 6. С. 303-315.

29. Айбабина Е. А., Бочаров С. Г. Отчет об археологических исследованиях в окрестностях Каффы в 1998 и 2000 годах // Научный архив Крымского филиала Института археологии Национальной академии наук Украины. Инвентарная книга 4. Инвентарный № 619. Папка 1018. 2001. Л. 1-152. 
30. Волков И. В. Импортная амфорная тара золотоордынских городов. Северное Причерноморье и Поволжье во взаимоотношениях Востока и Запада в XII-XVI вв. / Под ред. Г. А. Федорова-Давыдова. Ростов-на-Дону: Издательство Ростовского университета, 1989. С. 87-96.

31. Масловский А. Н. Керамический комплекс Азака. Краткая характеристика // Историко-археологические исследования в г. Азове и на Нижнем Дону в 2004 г. Азов: Компьютерный центр Азовского историко-археологического и палеонтологического музея-заповедника, 2006. Вып. 21. С. 309-473.

32. Масловский А. Н. Подвал купеческого дома конца первой половины XIV века из Азака // Степи Европы в эпоху средневековья. Донецк: Издательство Донецкого государственного университета, 2008. Т. 6. С. 93-124.

33. Бочаров С. Г., Масловский А. Н. Византийская поливная керамика в городах Северного Причерноморья золотоордынского периода (вторая половина XIII - конец XIV вв.) // Поволжская археология. 2012. Вып 1. С. 20-37.

34. Волков И. В. Керамика Азова XIV-XVIII вв. (классификация и датировка). Автореф. дис. ... канд. ист. наук. М.: МГУ имени М. В. Ломоносова, 1992. 20 с. 1 таб.

35. Айбабина Е. А., Бочаров С. Г. Раскопки в Феодосии // Археологические исследования в Крыму. 1994 год / Под ред. В. А. Кутайсова. Симферополь: Издательство Харьков, 1997. С. 16-19.

36. Айбабина Е. А., Бочаров С. Г. Археологические исследования Каффы // Археологические исследования в Крыму. 1995 год / Под ред. В. Л. Мыца. Симферополь: Сонат, 2007. С. 17-19.

37. Волков И. В. Поливная керамика могильника Черный-Ерик-1 // Тезисы докладов II Международной научной конференции «Поливная керамика Восточной Европы, Причерноморья и Средиземноморья в X-XVIII вВ.» / Под ред. С. Г. Бочарова. Ялта: Издательство Вендеревских, 2007. С. 26-33.

\section{References (transliterated):}

1. Volkov I. V. Gostevaya tserkov' - mechet' Bayazida Veli v Azove // Istoriko-arkheologicheskie issledovaniya v g. Azove i na Nizhnem Donu v 1989 g. Azov: Izdatel'stvo Azovskogo kraevedcheskogo muzeya, 1990. Vyp. 9. S. 136-150.

2. Volkov I. V. Oboronitel'nye sooruzheniya venetsianskoi Tany (XV v.) // Rezyume soobshchenii XVIII Mezhdunarodnogo kongressa vizantinistov. Moskva: Predpriyatie «POINT», 1991. Ch. II. S. 1236-1237.

3. Volkov I. V. Azovskaya krepost' glazami Evlii Chelebi i russkikh voennykh topografov XVII-XVIII vv. // Istoricheskaya geografiya Dona i Severnogo Kavkaza / Pod red. V. E. Maksimenko i V. N. Koroleva. Rostov-na-Donu: Izdatel'stvo Rostovskogo universiteta, 1992. S. 83-94.

4. Karpov S. P. Venetsianskaya Tana po aktam kantslera Benedetto B'yanko (1359-1360 gg.) // Prichernomor'e v Srednie veka / Pod red. S. P. Karpova. SPb.: Aleteiya, 2001. Vyp. 5. S. 9-26.

5. Maslovskii A. N. Zametki po topografii zolotoordynskogo goroda Azaka // Genuezskaya Gazariya i Zolotaya Orda / Pod red. S. G. Bocharova i A. G. Sitdikova. Kazan'; Simferopol'; Kishinev: Stratum, 2015. S. 383-411.

6. Karpov S. P. Latinskaya Romaniya. SPb.: Aleteiya, 2000. 253 c.

7. Thiriet F. De l'importance des mers dans le système romaniote de Venise // Byzantino Bulgarica. 1981. Vol. 1. R. 73-86.

8. Martin M. The Venetians in the Black Sea: a general survey // Rivista di Bizantinistica. 1993. T. 2. R. 227-248.

9. Nystazopoulou-Pélékidis M. Venise et la mer Noir du XIe au XVe siècle // Thesaurismata. 1970. Vol. 7. R. 15-51.

10. Diplomatarium Veneto-Levantinum, sive Acta et Diplomata res Venetas, Graecas atque Levantis illustrantia. 1880. A. 1300-1350 / Ed. by G. M. Thomas. P. 1. Venetiis: Sumptibus Societatis, 1880. 396 p.

11. Skrzhinskaya E. Ch. Petrarka o genueztsakh na Levante // Vizantiiskii vremennik. 1949. Vyp. 2 (27). S. 245-266.

12. Diplomatarium Veneto-Levantinum, sive Acta et Diplomata res Venetas, Graecas atque Levantis illustrantia. 1899. A. 1351-1454 / Ed. by R. Predelli. P. 2. Venetiis: Sumptibus Societatis, 1899. 278 p.

13. Grigor'ev A. P., Grigor'ev V. P. Uvedomlenie pravitelya Kryma Ramadana venetsianskim kuptsam v Yangishekhre (1356 g.) // Vostokovedenie. 1997. Vyp. 36. S. 155-159.

14. Grigor'ev A. P., Grigor'ev V. P. Kollektsiya zolotoordynskikh dokumentov iz Venetsii. SPb.: Izdatel'stvo Sankt-Peterburgskogo universiteta, 2002. $274 \mathrm{c}$.

15. Karpov S. P. Putyami srednevekovykh morekhodov. Chernomorskaya navigatsiya Venetsianskoi respubliki v XIII-XV vv. M.: Vostochnaya literatura, 1994. 158 c.

16. Grigor'ev A. P. Zolotoordynskii gorod Yagnishekhr // Vestnik Leningradskogo gosudarstvennogo universiteta. Ser. 2. 1994. Vyp. 2. S. 28-38.

17. Vasiliev A. A. The goths in the Crimea. Cambridge, Massachusetts: The Medieval Academy of America, 1936.293 p.

18. Balard M. La Romanie Génoise (XIII-e - début du XV-e siécle). Roma; Genova: Boccard, 1978. T. 1. 494 p.

19. Basso E. Il "bellum de Sorchati” ed i trattati del 1380-1387 tra Genova e l'Ordo d'Oro // Studi genuensi. 1991. Vol. VIII. R. 11-26.

20. Fomenko I. K. Obraz mira na starinnykh portolanakh. Prichernomor'e. Konets XIII - XVII v. M.: Indrik, 2007. 396 S.

21. Bocharov S. G. Zametki po istoricheskoi geografii genuezskoi Gazarii XIV-XV vekov // Problemy istorii i arkheologii Ukrainy. Materialy mezhdunarodnoi nauchnoi konferentsii. Khar'kov: Izdatel'stvo Khar'kovskogo natsional'nogo universiteta, 2001. S. 89-90.

22. Fomenko I. K. Nomenklatura geograficheskikh nazvanii Prichernomor'ya po morskim kartam kontsa XIII - XVII vv. // Prichernomor'e v srednie veka / Pod red. S. P. Karpova. SPb.: Aleteiya, 2003. Vyp. 3. S. 40-108.

23. Belyanskii I. L., Lezina I. N., Superanskaya A. V. Krym. Geograficheskie nazvaniya. Simferopol': Tavriya Plyus, 1998.160 s.

24. Delatte A. Les portulans grecs. Liège: Université de Liège, 1947. 399 p.

25. Bocharov S. G. Rubezh XIII-XIV vv. po materialam keramicheskogo kompleksa poseleniya Posidima (Koktebel') // Tezisy II Mezhdunarodnoi nauchnoi konferentsii «Polivnaya keramika Vostochnoi Evropy, Prichernomor'ya i Sredizemnomor'ya v X-XVIII vv.» / Pod red. S. G. Bocharova. Yalta: Izdatel'stvo Venderevskikh, 2007. S. 12-18.

26. Bocharov S. G. Srednevekovoe selenie Posidima (Koktebel', Krym) // Vestnik Kazanskogo gosudarstvennogo universiteta kul'tury i iskusstv. 2015. Vyp. 3. S. 123-127. 


\section{Исторический журнал: научные исследования № 6 (30) • 2015}

DOI: $10.7256 / 2222-1972.2015 .6 .17435$

27. Bocharov S. G. Zametki po istoricheskoi geografii Genuezskoi Gazarii XIV-XV vekov (Kampan'ya Kaffy) // Dialog gorodskoi i stepnoi kul'tur na evraziiskom prostranstve. Materialy Mezhdunarodnoi nauchnoi konferentsii, posvyashchennoi 80-letiyu so dnya rozhdeniya G. A. Fedorova-Davydova / Pod red. D. V. Vasil'eva, Yu. A. Zeleneeva i A. G. Sitdikova. Kazan': Izdatel'stvo Instituta istorii Akademii nauk Respubliki Tatarstan, 2011.137-145.

28. Bocharov S. G. Venetsianskoe prisutstvie v Krymu i yakornaya stoyanka Provato v 1356-1382 gg. // Stratum Plyus. 2015. Vyp. 6. S. 303-315.

29. Aibabina E. A., Bocharov S. G. Otchet ob arkheologicheskikh issledovaniyakh v okrestnostyakh Kaffy v 1998 i 2000 godakh // Nauchnyi arkhiv Krymskogo filiala Instituta arkheologii Natsional'noi akademii nauk Ukrainy. Inventarnaya kniga 4. Inventarnyi № 619. Papka 1018. 2001. L. 1-152.

30. Volkov I. V. Importnaya amfornaya tara zolotoordynskikh gorodov. Severnoe Prichernomor'e i Povolzh'e vo vzaimootnosheniyakh Vostoka i Zapada v XII-XVI vv. / Pod red. G. A. Fedorova-Davydova. Rostov-na-Donu: Izdatel'stvo Rostovskogo universiteta, 1989. S. 87-96.

31. Maslovskii A. N. Keramicheskii kompleks Azaka. Kratkaya kharakteristika // Istoriko-arkheologicheskie issledovaniya v g. Azove i na Nizhnem Donu v 2004 g. Azov: Komp'yuternyi tsentr Azovskogo istoriko-arkheologicheskogo i paleontologicheskogo muzeya-zapovednika, 2006. Vyp. 21. S. 309-473.

32. Maslovskii A. N. Podval kupecheskogo doma kontsa pervoi poloviny XIV veka iz Azaka // Stepi Evropy v epokhu srednevekov'ya. Donetsk: Izdatel'stvo Donetskogo gosudarstvennogo universiteta, 2008. T. 6. S. 93-124.

33. Bocharov S. G., Maslovskii A. N. Vizantiiskaya polivnaya keramika v gorodakh Severnogo Prichernomor'ya zolotoordynskogo perioda (vtoraya polovina XIII - konets XIV vv.) // Povolzhskaya arkheologiya. 2012. Vyp 1. S. 20-37.

34. Volkov I. V. Keramika Azova XIV-XVIII vv. (klassifikatsiya i datirovka). Avtoref. dis. ... kand. ist. nauk. M.: MGU imeni M. V. Lomonosova, 1992. 20 s. 1 tab.

35. Aibabina E. A., Bocharov S. G. Raskopki v Feodosii // Arkheologicheskie issledovaniya v Krymu. 1994 god / Pod red. V. A. Kutaisova. Simferopol': Izdatel'stvo Khar'kov, 1997. S. 16-19.

36. Aibabina E. A., Bocharov S. G. Arkheologicheskie issledovaniya Kaffy // Arkheologicheskie issledovaniya v Krymu. 1995 god / Pod red. V. L. Mytsa. Simferopol': Sonat, 2007. S. 17-19.

37. Volkov I. V. Polivnaya keramika mogil'nika Chernyi-Erik-1// Tezisy dokladov II Mezhdunarodnoi nauchnoi konferentsii «Polivnaya keramika Vostochnoi Evropy, Prichernomor'ya i Sredizemnomor'ya v X-XVIII vv.» / Pod red. S. G. Bocharova. Yalta: Izdatel'stvo Venderevskikh, 2007. S. 26-33. 